\title{
Design of RFID based Location Aware System to Mitigate Child Kidnapping in Nigerian Nursery and Primary Schools
}

\author{
Opeyemi Emmanuel Matiluko \\ Computer Science Dept, University of Ilorin \\ Ilorin, Kwara State,
}

Nigeria

\author{
Dayo Reuben Aremu, PhD \\ Computer Science Dept, University of Ilorin \\ Ilorin, Kwara State, \\ Nigeria
}

\begin{abstract}
Today, kidnapping cases in Nigeria is on the daily increase and children in nursery and primary schools are not left out. These innocent children are lured with precious items and food items and kidnapped even from school premises. To curb this act of kidnapping in schools, security men are employed to watch the gates but they cannot always determine the guardian-ward relationship of all pupils easily. It is believed that this can be curbed if the guardian-ward relationship can be determined easily and the location of all pupils can also be known per time.

Today, there exist various means by which the locations of people, animal or items can be tracked real time, some of which were explored including Global positioning system (GPS), mobile phone tracking etc. but all come with their limitation especially cost of implementation. This work thus proposes a cost-effective location-aware system design integrating Radio Frequency Identification (RFID), which is able to determine the location of pupils per time within the school premises, and also map and determine guardian-ward relationship.
\end{abstract}

\section{General Terms}

Radio Frequency Identification (RFID).

\section{Keywords}

RFID; location aware system; kidnapping; Passive Tag.

\section{INTRODUCTION}

Kidnapping cases in Nigeria today are daily on the increase; these cases of kidnapping have not only affected expatriates working in Oil companies in the Niger-Delta oil rich regions but have also extended to the none oil rich locations. Today, cases of kidnapping have extended to the kidnapping of locals, children, professionals (e.g. Medical Practitioners, Bankers etc.), traditional leaders, government official and their family members [1].

Kidnapping of children, which has been in existence for a while has taken a new turn in recent years. Perpetrators of this heinous act have extended their reach to kidnapping children from school premises and this has left a lot of school proprietors and stakeholders in great dilemma. In the quest to forestall such occurrence, security guards are employed but the activities of such security officers are limited as identification and relationship of the guardian to their wards cannot always be easily linked by such personnel [1]. This work is thus focused on designing a location-aware system that will incorporate guardian-ward relationship factor in its design using Radio Frequency Identification (RFID).

\section{RELATED WORKS}

\subsection{Early Location Awareness Technology}

Location determination or location awareness technology is a technology that has been in existence for a while. RAdio Detection And Ranging (RADAR) technology is one of the first highly successful location determination technologies. According to Curran \& Norrby [2], "many engineers and scientists, including Nikola Tesla, had worked on the principles of radar in the early part of the twentieth century. Several systems were patented in the 1930s in the United States, Germany and France. However, the British were the first to use radar as a defence from enemy aircraft attacks, with Robert Watson-Watt's 1935 patent GB593017. The Second World War brought about a large push in radar research on both the allied and axis sides".

\subsection{Modern Location Awareness Technologies}

With the improvement and advancements experienced in terms of technologies, location awareness and determination technologies have evolved over the years. Today, there are a number of such technologies, all with their pros and cons depending on their applications.

\subsubsection{Global Positioning System}

Global Positioning System (GPS) is a technology developed by the United States Department of Defense (DoD), as a satellite based navigation system. Two pseudorandom noise (PRN) codes are transmitted by GPS, viz. C/A and P-code, on two L-band frequencies $\left(f_{1}=1575.42 \mathrm{MHz}, f_{2}=1227.60\right.$ $\mathrm{MHz}$ ), which a GPS receiver processes and in turn provides information about position, velocity and time [3]. GPS was originally designed for military use, but was released for civilian use at no cost in 1983 by President Ronald Reagan, following the Korean Air Lines Flight 007 that was shot down by the Soviet Air Force after entering Soviet airspace mistakenly. The President believed that the tragedy could have been averted if better navigation system was available to the flight crew [4].

GPS is designed to provide users with information pertaining to position, navigation and timing. The GPS is designed with three segments, which are space, control and user segments. The space segment comprises the GPS satellites moving in defined pattern in orbit around the earth while the control segment is coordinated by the United States Air Force to maintain and control the activities and movements of the satellites in orbit. The United States is committed to maintaining at least 24 operational satellites in orbit per time but in the past few years, there are about 31 operational GPS 
satellites in orbit. These GPS satellites fly in medium Earth orbit (MEO) at an altitude of approximately 20,200 km $(10,907.13$ Nautical Miles). Each satellite circles the Earth twice a day [5].

\subsubsection{Mobile Phone Tracking}

Mobile phones, when switched on, send out a signal to cell towers within its vicinity and the mobile phone can be identified with this signal. By comparing the time for the signal to arrive and relative signal strengths from multiple towers, an estimated location of the handset can be obtained.

Mobile phone identifies itself in two ways when it connects to the mobile phone network. The SIM card sends its unique IMSI number - standing for International Mobile Subscriber Identity. The IMSI number starts with the country code of the user's account, followed by the network code and finally the telephone number. The second number is the IMEI International Mobile Equipment Identity. This is the number of the handset and remains constant even if the SIM card is changed. Mobile phones transmit these numbers each time they make a call and when they regularly "check in" to the local base stations; making it possible to track even without making calls [6].

\subsubsection{Radio Frequency Identification}

Radio Frequency Identification (RFID), is a technology used for the automatic identification and tracking of goods, animals and people. RFID uses radio-frequency electromagnetic fields to transfer data wirelessly without making contact, for the purposes of automatically identifying and tracking tags attached to objects, which contain electronically stored information. Some tags can be powered by and read at short ranges (a few meters) via magnetic fields (electromagnetic induction) while others use a local power source such as a battery, or else have no battery but collect energy from the interrogating EM field, and then act as a passive transponder to emit microwaves or UHF radio waves (i.e., electromagnetic radiation at high frequencies). Battery powered tags may operate at hundreds of meters [7].

The major difference between bar code and RFID is that the RFID tag does not necessarily need to be within line of sight of the reader, and may be embedded in the tracked object unlike bar code which is required to be in the line of sight of the reader.

\subsubsection{Components of an RFID System}

The following is the list of the major components of an RFID system.
- RFID Tag/Transponder
- Reader
- Control Software [8]

\subsubsection{Current Application of RFID}

RFID technology has been implemented in various areas and fields of life. Some of its recent application includes but not limited to the following;

- Automated toll payment system

- Metro station fare payment

- Protection of infants in hospitals

- Automated entry/access system.

\subsubsection{Comparison of Modern Location Awareness} Technologies

This sub-section considers the pros and cons of all three (3) modern location awareness technologies discussed under the parent section, which are; radio frequency identification
(RFID), global positioning system and mobile phone tracking. The comparison is based on a number of factors, which include;

- Cost of deployment

- $\quad$ Ease of handling

- Rate of Power Consumption/ Power requirement

- Line of sight requirement

- Indoor performance of the technologies

Table 1: Comparison of modern location awareness technologies

\begin{tabular}{|c|c|c|c|}
\hline & RFID & GPS & $\begin{array}{c}\text { Mobile } \\
\text { Tracking }\end{array}$ \\
\hline Cost & $\begin{array}{l}\text { Minimal } \\
\text { Cost of } \\
\text { deployment }\end{array}$ & $\begin{array}{l}\text { High Cost } \\
\text { of } \\
\text { deployment }\end{array}$ & $\begin{array}{l}\text { Medium to } \\
\text { high cost of } \\
\text { deployment }\end{array}$ \\
\hline $\begin{array}{l}\text { Ease of } \\
\text { Handling }\end{array}$ & $\begin{array}{l}\text { Tags can be } \\
\text { in form of } \\
\text { Identity } \\
\text { cards or } \\
\text { embedded } \\
\text { in pupil's } \\
\text { school bag } \\
\text { or shoes } \\
\text { without } \\
\text { damage to } \\
\text { the tag }\end{array}$ & $\begin{array}{l}\text { GPS device } \\
\text { cannot be } \\
\text { easily } \\
\text { managed } \\
\text { by little } \\
\text { school } \\
\text { children } \\
\text { and they } \\
\text { can easily } \\
\text { be detected } \\
\text { and } \\
\text { disposed by } \\
\text { assailant }\end{array}$ & $\begin{array}{l}\text { Mobile } \\
\text { device } \\
\text { cannot be } \\
\text { easily } \\
\text { managed by } \\
\text { little school } \\
\text { children and } \\
\text { they can } \\
\text { easily be } \\
\text { detected and } \\
\text { dispose by } \\
\text { assailant }\end{array}$ \\
\hline $\begin{array}{l}\text { Power } \\
\text { Consumption }\end{array}$ & $\begin{array}{l}\text { Passive tags } \\
\text { used is } \\
\text { powered by } \\
\text { the external } \\
\text { reader and } \\
\text { do not } \\
\text { require } \\
\text { internal } \\
\text { power to } \\
\text { run }\end{array}$ & $\begin{array}{l}\text { Internal } \\
\text { power is } \\
\text { required for } \\
\text { the GPS } \\
\text { device to } \\
\text { run }\end{array}$ & $\begin{array}{l}\text { Internal } \\
\text { power is } \\
\text { required for } \\
\text { the mobile } \\
\text { device to run }\end{array}$ \\
\hline Line of Sight & $\begin{array}{l}\text { No Contact } \\
\text { nor line of } \\
\text { Sight } \\
\text { necessary }\end{array}$ & $\begin{array}{l}\text { Line of } \\
\text { sight } \\
\text { required for } \\
\text { communica } \\
\text { tion with } \\
\text { the } \\
\text { satellites }\end{array}$ & $\begin{array}{l}\text { Line of sight } \\
\text { not required }\end{array}$ \\
\hline $\begin{array}{l}\text { Indoor } \\
\text { Performance }\end{array}$ & $\begin{array}{l}\text { Works } \\
\text { perfectly in } \\
\text { an indoor } \\
\text { environment }\end{array}$ & $\begin{array}{l}\text { Works } \\
\text { optimally } \\
\text { outdoor } \\
\text { where the } \\
\text { device has } \\
\text { access to } \\
\text { the sky } \\
\text { view }\end{array}$ & $\begin{array}{l}\text { Works } \\
\text { perfectly in } \\
\text { an indoor } \\
\text { environment }\end{array}$ \\
\hline
\end{tabular}

From table 1 above, Radio Frequency Identification (RFID) has a plus over the other two (2) technologies in terms of Cost of deployment, ease of handling, power consumption and indoor performance. The ease of handling is the major factor considered in the choice of technology employed in this design as young pupils are involved. 


\section{METHODOLOGY}

A study of Radio Frequency Identification (RFID) technology and its current application was carried out and a design which maps guardian-ward relationship is proposed using the RFID tag/transponder's information particularly the TagID, which is unique. The proposed design is presented in this paper.

\section{RFID Based location aware system with Guardian-ward relationship}

This section presents the design proposed for the RFID based location aware system that incorporates guardian-ward relationship to assist security officials employed at nursery and primary schools to determine when a pupil is taken out of the premises by anyone other than the parent/guardian.

Figure 1 below is a flowchart representation of the proposed design. The incorporation of the Guardian-ward relationship is outlined in the flowchart. The system monitors designated area indoors or outdoors, such as a classroom or school compound, using the RFID readers. Several antennas are placed in different locations around the school premises giving it maximum coverage and the unit is attached to a desktop or laptop computer.

RFID tags/transponders in form of identity cards (PVC card) are issued to all pupils and their parents/guardian. Other forms of RFID tags can be embedded in the pupils' school sandals and bags in schools where such items are given to pupils during admission or resumption exercise. The pupil's assigned tag is then linked to that of the parent and the information stored in the database.

According to the proposed design, the exit points of the school premises serves as the major target of this work. All RFID units at all exit points are monitored by the security personnel; every time a pupil's tag is detected at the exit point, the system automatically checks if the pupil's tag has been linked to a parent/guardian. If it is linked the system checks the tags detected at that same exit point for the parent's/guardian's tag, if it is detected no alarm is raised otherwise the system alerts the security personnel at that point with the detail and image of the pupil for easy identification and questioning,

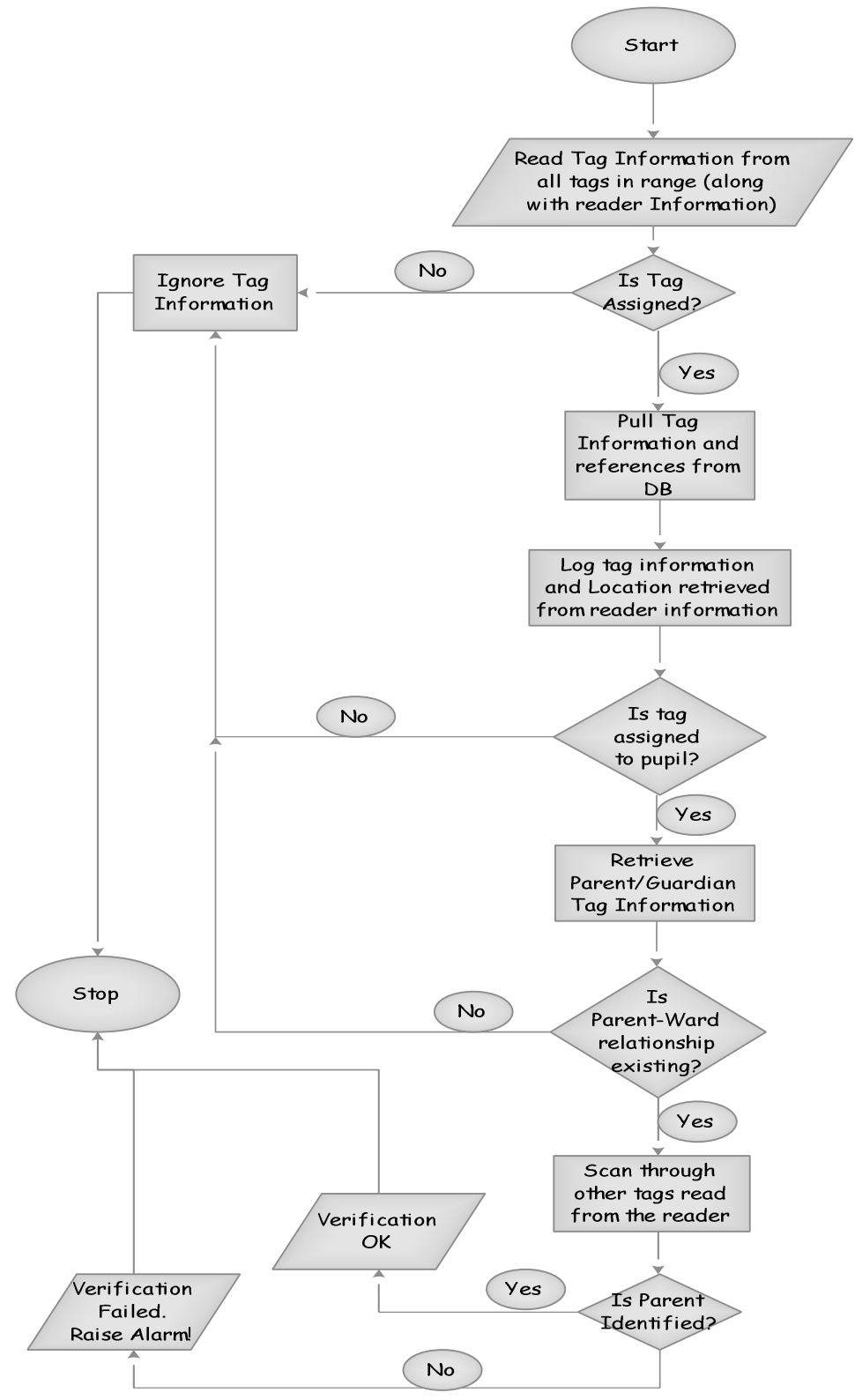

Figure 1: Flowchart for the proposed Guardian-Ward Matching 


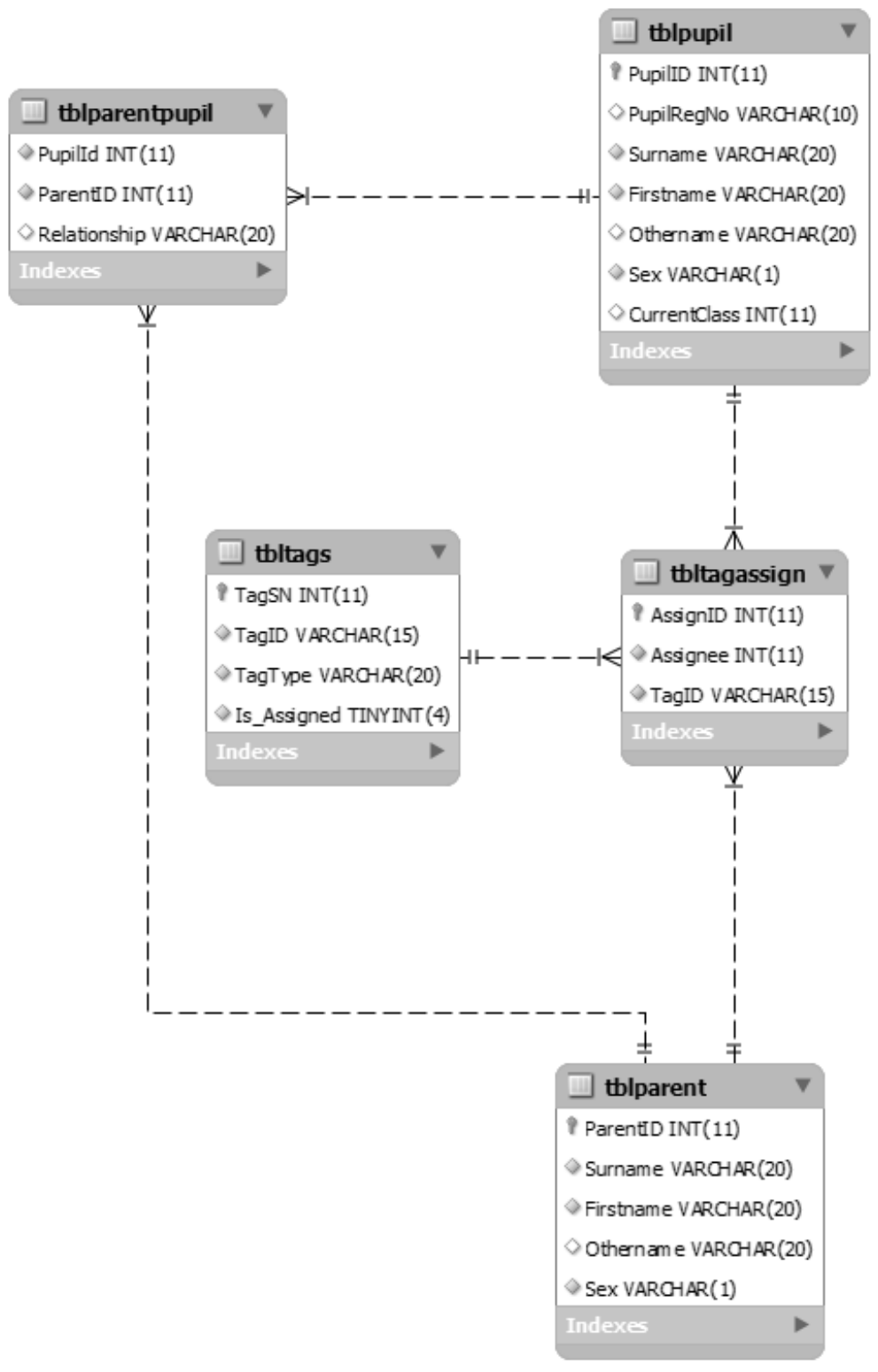

Figure 2: Object representation in ER Diagram

Figure 2 above gives an Entity relationship diagram of the proposed system showing the relationship between all identified entities.

\section{CONCLUSION}

This work documents the design of a cost-effective locationawareness system using radio frequency identification (RFID) in tackling one of the nation's current dilemmas, kidnapping, in Nigeria nursery and primary schools.

To gain better understanding of the subject matter, the review of relevant works was covered in chapter two. A review of early and modern location determination systems was studied and documented. A comprehensive study of RFID, its evolution and uses was also covered to understand why the technology was adopted for this work.

A design for the systems was developed and proposed to be implemented using programming tools such as VB.net along with MySQL database system. The system is designed to alert security men at all exit points in the premises when a pupil tag is detected and that of the parent is nowhere to be found. It is, however, believed that this will assist security personnel employed in schools in easy determination of guardian-ward relationship. This will deter a stranger from picking up pupils from the school premises.

\section{FUTURE WORK}

The scope of this work was only limited to the use of RFID in preventing kidnapping from school premises, with some modification, it can be extended to cater for other needs including theft prevention. The design can also be implemented in a real-life scenario. 


\section{REFERENCES}

[1] Okengwu, K. (2011). "Kidnapping in Nigeria: Issues and common sense ways of surviving". Global Journal of Educational Research, 1(1), 1 - 8. Retrieve from http://www.globalresearchjournals.org/fullarticle/51404c b04bdbb.

[2] Curran, K., \& Norrby, S. (2009), RFID-Enabled Location Determination within Indoor Environments. International Journal of Ambient Computing and Intelligence (IJACI), Volume 1, Issue 4, Article 5, pages 63-86. http://www.igi-global.com/article/rfid-enabledlocation-determination-within/37476.

[3] Hofmann-Wellenhof, B., Lichtenegger, H., \& Collins, J. (2001), Global Positioning System Theory and Practice, $5^{\text {th }}$ edn. Springer-Verlag Wien New York

[4] Pellerin, C. (2006), United States Updates Global Positioning System Technology - Available at: http://usinfo.state.gov/xarchives/display.html?p=washfile -english \&y=2006\&m=February\& $=200602031259281$ cnirellep0.5061609

[5] Space Segment (2013). Retrieved December 25, 2013, from_http://www.gps.gov/systems/gps/space/

[6] Tracking a suspect by any mobile phone (2005). $B B C$ News. 03-08-2005. Retrieved December 19, 2013, from http://news.bbc.co.uk/2/hi/technology/4738219.stm.

[7] Radio-frequency identification (2013). Wikipedia. Retrieved September 20, 2013 from http://en.wikipedia.org/wiki/Radio_frequency_identificat ion

[8] Norrby, S. (2008). Continous RFID-enabled location awareness. (Bachelor Thesis, University of Ulster, United Kingdom). Retrieved from http://scisweb.ulster.ac.uk/ kevin/stephen.zip 